\title{
MAGNETIC RESONANCE IMAGING FINDINGS IN CEREBRAL VENOUS THROMBOSIS DUE TO BEHCET'S DISEASE AND THE IMPORTANCE OF SUSCEPTIBILITY-WEIGHTED IMAGING: CASE REPORT
}

\author{
Mehmet Deniz BULUT*, Alpaslan YAVUZ*, Aysel MILANLIOĞLU**, Aydın BORA*, İsmail GÜLŞEN*** \\ *Yüzücü Yıl University Faculty of Medicine, Department of Radiology, Van, TURKEY \\ **Yüzücü Yıl University Faculty of Medicine, Department of Neurology, Van, TURKEY \\ ***Yüzücü Yıl University Faculty of Medicine, Department of Neurosurgery, Van, TURKEY
}

\begin{abstract}
Cerebral venous thrombosis (CVT) is an uncommon disorder that can lead to an unfavorable prognosis and even be fatal in some cases. CVT is seen mainly in females, especially those between the ages of 20 and 35 years. The disorder has many etiologic factors. This report presents the case of a 34-year-old male patient with Behçet's disease admitted with complaints of headache and vomiting. The major venous vascular structures that were visible in cranial magnetic resonance imaging (MRI) and MR venography were found to be filled with thrombosis. The patient's susceptibilityweighted imaging (SWI) revealed marked hypointensities consistent with thrombosis in the transverse sinus, sigmoid sinus, and in the venous vascular structures of the posterior fossa. Thus, it was found that cerebral venous thrombosis due to Behçet disease could clearly be determined by the SWI sequence; in addition, thrombosis by the venous vascularity in veins of the posterior fossa were more visible than via the other MR sequences. The conclusion was made that SWI can promptly demonstrate cerebral venous thrombosis, contribute to the diagnosis, and provide useful additional information. Key Words: Neuro-Behçet's disease, cerebral venous thrombosis, magnetic resonance imaging, susceptibility-weighted imaging.
\end{abstract}

\section{BEHÇET HASTALIĞINA BAĞLI SEREBRAL VENÖZ TROMBÜS MANYETIK REZONANS BULGULARI VE SUSEPTIBBiLİTE-AĞIRLIKLI GÖRÜNTÜLEMENIN ÖNEMİ: OLGU SUNUMU}

\section{ÖZET}

Serebral venöz tromboz (SVT) bazı vakalarda kötü prognozda seyreden ve fatal sonuçlanabilen nadir görülen bir durumdur. SVT başlıca 20 ile 35 yaş arasındaki bayan hastalarda daha sık görülmektedir. Hastalık çeşitli etyolojk faktörlere sahiptir. Bu sunuda Behçet hastalığı nedeniyle takip edilen, hastanemize kusma ve baş ağrısı şikayetleri ile başvuran otuz dört yaşındaki erkek hasta presente edildi. Kranyal konvansiyonel manyetik rezonans görüntüleme (MRG), MR venografi görüntülemede izlenebilen majör venöz vasküler yapıların tromboze olduğu görüldü. Suseptibilite ağırlıklı (SWI) sekans görüntülerde transvers sinüs, sigmoid sinüs ve posteriyor fossadaki venöz yapılarda trombozla uyumlu belirgin hipointensiteler izlendi. Böylelikle SWI sekansının Behçet Hastalığına bağlı oluşan venöz trombozu net bir şekilde tesbit ettiği, ayrıca özelikle posteriyor fossada parankim içi venöz yapllardaki trombozu diğer sekanslara göre daha iyi gösterdiği izlendi. Sonuç olarak, SWI sekans venöz trombozu hızlı bir șekilde saptayabilir, tanıya yardımcı olur ve ek faydalı bilgiler verebilir.

Anahtar Sözcükler: Nöro-Behçet hastalığı, serebral venöz tromboz, manyetik rezonans görüntüleme, suseptibilite ağırlıklı görüntüleme.

\footnotetext{
Corresponding author: Ass. Prof. Alparslan Yavuz, MD. Yüzüncü Yıl University Faculty of Medicine, Department of Radiology, Van, Turkey.

Phone: +900432 $2150470 \quad$ E-mail: alp_yavuz@hotmail.com

Received: 22.07.2014 Accepted: 30.10.2014

This article should be cited as following: Bulut M. D, Yavuz A, Milanlığlu A, Bora A, Gülșen İ. Magnetic rezonance imaging findings in cerebral venous thrombosis due to Behcet's Disease and the importance of susceptibility-weighted imaging: Case report. Turkish Journal of Cerebrovascular Diseases 2015; 21 (2): 204-209. doi:10.5505/tbdhd.2015.07830.
} 


\section{INTRODUCTION}

Cerebral venous thrombosis (CVT), a rare disorder that can lead to an unfavorable prognosisand even be fatal in some cases, is seen mainly in females, especially those between the ages of 20 and 35 years (1). Cerebral venous sinus thrombosis occursless often than arterial ischemic stroke (2). Oral contraceptives, coagulopathies, intracranial infections, cranial tumors, penetrating head traumas, lumbar puncture, malignancies, dehydration, inflammatory bowel disease, connective tissue diseases, Behçet's disease, sarcoidosis, nephrotic syndrome, parenteral infusions, and various medications may cause CVT (3). Neuro-Behçet's disease is Behçet's disease with central nervous system involvement. The prevalence range of neurological complications in Behçet's disease is $3-10 \%$ (4). The clinical symptomatology and findings of CVT caused by Behçet's disease are quite similar to those of CVT caused by other etiologies (5). In general, it has a subacute onset and is frequently accompanied by nausea, vomiting, and severe headache that intensifies in the supine position. Papilledema and unilateral or bilateral sixth cranial nerve palsy can also be observed. The remaining neurological examination and neuro-psychological findings are normal. However, in contrast to CVT due to other etiological causes, epileptic seizures and venous infarcts are less frequent in CVT due to neuroBehçet's disease (5).

Susceptibility-weighted imaging (SWI) is a relatively new neuro-imaging method. It is a highresolution, gradient-echo magnetic resonance imaging (MRI)technique that exploits the differences insusceptibility among tissues such as blood products, iron, and calcifications, and uses the phase image to detect these differences. SWI can contribute to the diagnosis of hemorrhagic cerebral diseases, ischemic cerebrovascular diseases, vascular malformations, tumors, neurodegenerative diseases, trauma, vasculitis, epilepsy, and multiple sclerosis $(6,7)$.

In the literature, papers on MRI and MR venography findings in CVT involving the venous vascular structures that can be visualized by MR venography due to Behçet's disease are quite rare, and, as far as we know, this paper is the first on the subject to present SWI findings.

\section{CASE}

A 34-year-old male patient with Behçet's disease presented to our hospital with complaints of headache. His complaint started ten days prior to presenting at our hospital, and it worsened gradually. He had severe, intractable, throbbing, bilateral frontotemporal headache accompanied by nausea, vomiting, phonophobia, and photophobia. His previous history revealed several admissions for headache with similar characteristics that improved with analgesics. The patient had had a Behçet's disease diagnosis for five years, based on the presence of recurrent oral and genital ulcers, positive pathergy test, and history of arthralgia. He had been treated with colchicine, which inhibits neutrophil hyperfunction for mucocutaneous lesions. On admission, his vital signs were as follows: body temperature $36.6^{\circ} \mathrm{C}$; blood pressure $130 / 80$ $\mathrm{mmHg}$; pulse rate $72 / \mathrm{min}$; and respiratory rate $18 /$ min. The patient's physical examination was normal. On the neurological examination, his pupils were isochoric, and direct and indirect light reflexes and external eye movements were normal. On the fundoscopic examination, the margins of the bilateral optic disks were minimally indistinct, and this finding was interpreted in favor of increased intracranial pressure. The other neurological examination findings revealed normal sensory, motor, and cerebellar functions, with normoactive deep tendon reflexes without any signs of neck stiffness. Prothrombotic studies, including levels of protein $\mathrm{S}$, protein $\mathrm{C}$, antithrombin III, fibrinogen, factor VIII, and activated protein $\mathrm{C}$ resistance were normal; anti-cardiolipin antibody, lupus anticoagulant, factor $\mathrm{V}$ Leiden, and prothrombin 20210 mutation tests were negative. His platelet count was 384,000 platelets per microliter of blood (ranging 150,000-450,000). There was no evidence to suggest any systemic or pericranial infection. Unfortunately, a cerebrospinal fluid examination could not be performed, as the patient refused to allow the lumbar puncture. The patient had a history (four years prior) of deep venous thrombosis of the lower extremities (complete recovery with warfarin), which is suggestive of systemic Behçet's vasculitis.

The patient was screened with conventional 
MRI, MR venography, and SWI sequences (Siemens Symphony, 1.5 Tesla). Subtotal obstruction due to thrombosis within the superior sagittal sinus; bilateral transverse, sigmoid, and straight sinuses; and posterior fossa venous structures were determined by cranial MR and MR venography $2 \mathrm{D}$ and $3 \mathrm{D}$ TOF imaging. In addition, disseminated collateral flows were present in the cranium. The Galen vein, internal cerebral vein, bilateral Labbe veins, and left Trolard vein were patent; the right Trolard vein could not be visualized clearly. The SWI sequences revealed marked hypointensities consistent with thrombosis in the transverse sinus, sigmoid sinus, straight sinus, and venous vascular structures of the posterior fossa (Figures 1-3). Despite presence of thrombosis in the major venous structures that could be visualized with MR venography, there was no venous infarct. The thrombus was hyperintense in T1W, T2W, and FLAIR MR sequences, and hypointense in SWI sequence; thus, the thrombus was considered to be in its subacute period. Based on the imaging findings, the patient was diagnosed with CVT caused by Behçet's disease. In the acute phase, he was treated with intravenous methylprednisolone (1 g/day) combined with low molecular weight heparin and then continued with oral prednisolone (1 $\mathrm{mg} / \mathrm{kg} /$ day) and oral anticoagulant. His headache resolved, and the optic disk margins improved. At the three-month follow up, MRI venography demonstrated partial recanalization.

(A)

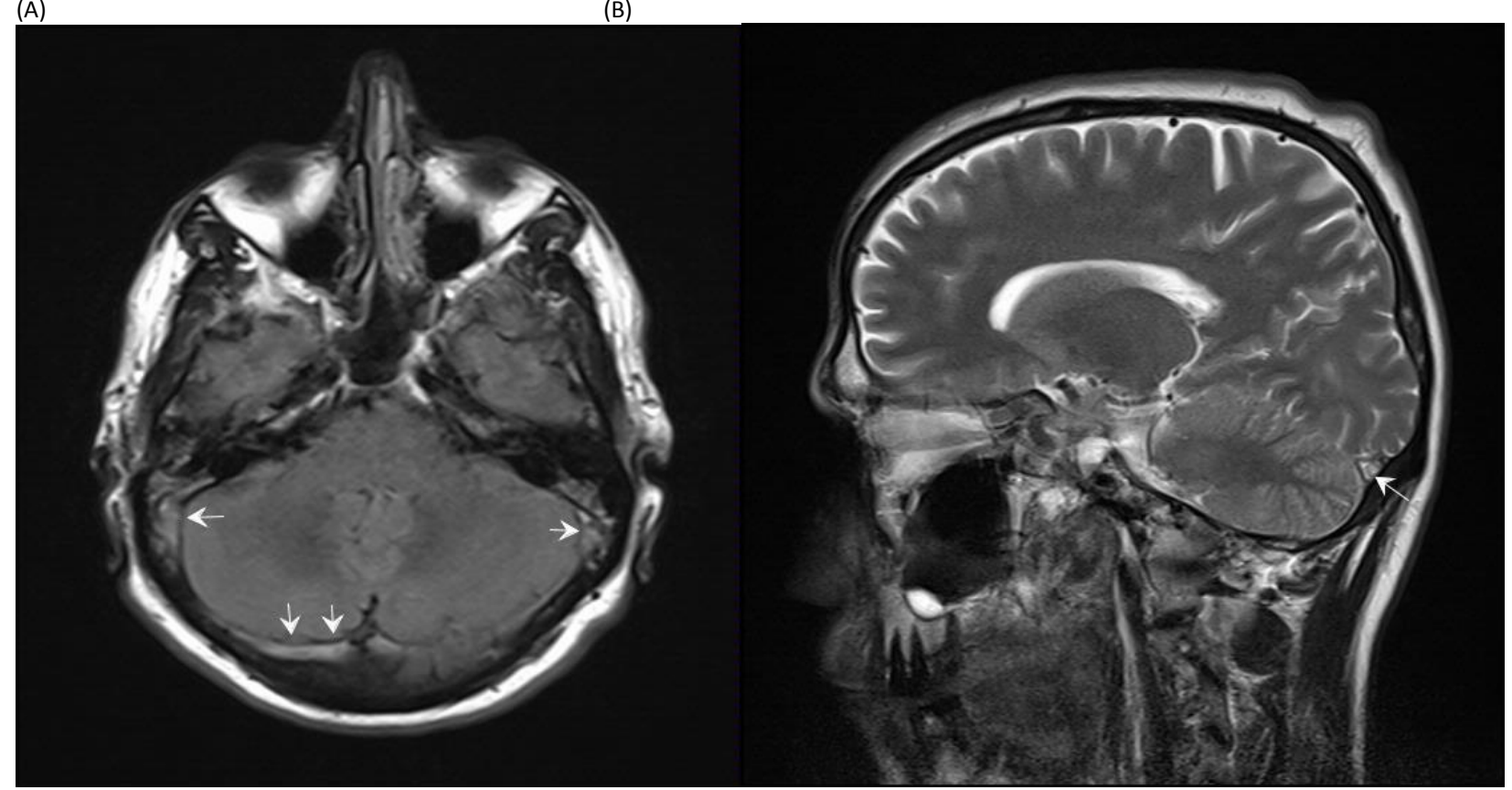

Figure 1. Hyperintensities in the transverse sinuses in axial FLAIR (A) and sagittal T2 (B) sections.

\section{DISCUSSION}

Although CVT has a wide spectrum of symptoms, its diagnosis is usually established by imaging techniques carried out upon clinical suspicion. Headache is the most common symptom of CVT (8). The most sensitive technique in establishing the diagnosis is MRI plus MRI venography (1). However, SWI has recently been reported as a dependable imaging method in diagnosing CVT (9). The sinuses most affected in CVT, in decreasing order of frequency, are the superior sagittal sinus, the transverse and the sigmoid sinus, the cavernous sinus, and the sinus rectus. More than one sinus is affected in one-third of cases (10). In our case of Behçet's disease, almost all of the major cerebral veins that could be visualized by MR venography had subtotal thrombosis. To date, the pathophysiologic mechanism of deep vein thrombosis in Behçet's disease remains unclear. However, it is thought to be a vasculitic process of the entire central nervous system, expressed by multifocal lesions with an inflammatory cell reaction or endothelial 
(A)

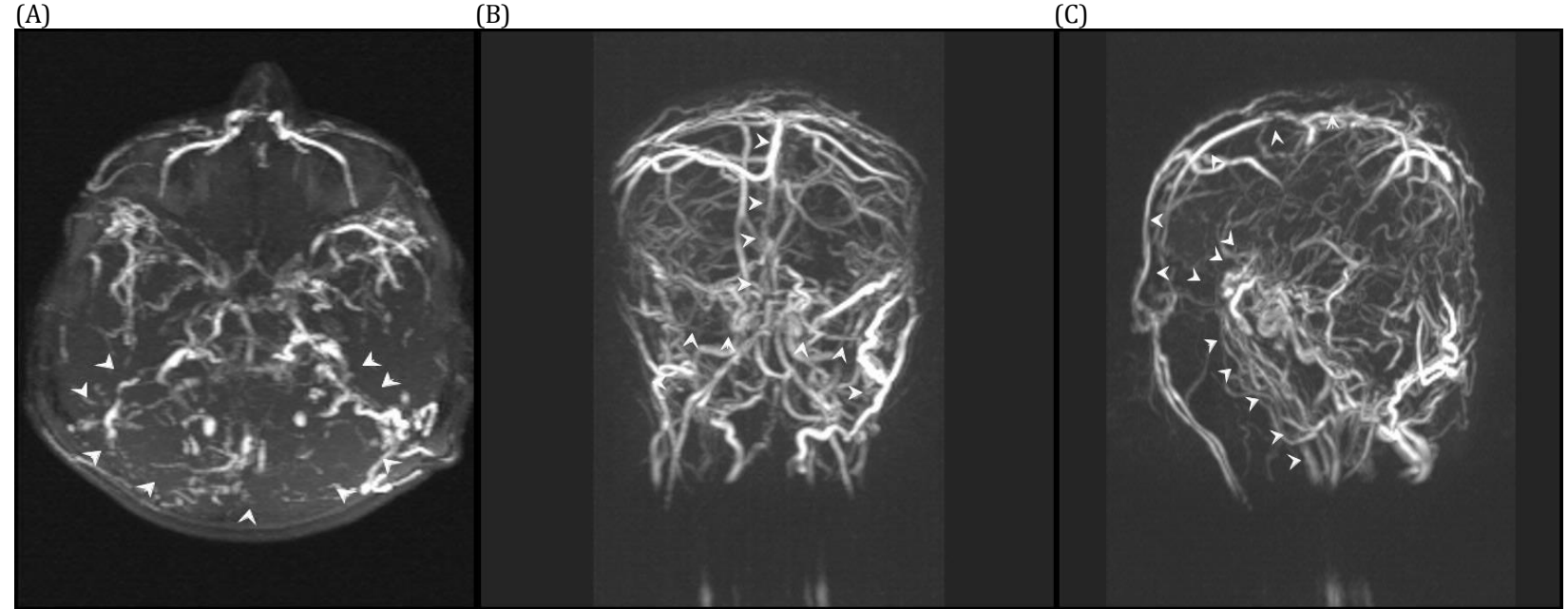

Figure 2. Thrombosis in visible vascular structures and extensive collateral flow in the cranium in $2 \mathrm{D}$ TOF superior projection (A); $3 \mathrm{D}$ TOF anterior and lateral projections (B and C) in MIP images of MR venography.

cell activation, which may obviously act together with endothelial dysfunction and concomitant prothrombotic factors, causing hypercoagulability (11). Two different mechanisms are responsible for the symptoms and findings of CVT. One mechanism involves the development of local effects by thrombosis of the cerebral veins, and the other mechanism is the increased intracranial pressure by thrombosis of the major sinuses. These two mechanisms are the main reasons for the clinical features of most patients. The occlusion of the cerebral veins leads to cerebral edema and venous infarct (1). In our case of Behçet's disease, althoughmost of the major cerebral venous vascular structures seen by MR venography had thrombosis, there was no infarct or hemorrhage.

SWI is a high-spatial-resolution, 3D, gradientecho MRI technique with phase post-processing that emphasizes the paramagnetic features of blood products, such as intracellular methemoglobin, deoxyhemoglobin, and hemosiderin. This technique is particularly useful in determining intravascular deoxygenated venous blood and extravascular blood products $(6,7)$.

SWI was first reported in 1986 as a method of diagnosing cerebral hemorrhage (12). It has been reported that SWI and computed tomography have similar sensitivity in diagnosing cerebral hemorrhage (13). It was later shown that SWI can be used in the diagnosis of cerebrovascular diseases (to determine the location of an arterial thrombus and ischemic penumbra in acute ischemic stroke), CVT, hemorrhagic cerebral diseases, vascular malformations, tumors, neurodegenerative disorders, trauma, vasculitis, epilepsy, and multiple sclerosis $(6,7,9,14)$.

SWI sequencing shows the normal anatomy of cerebral veins, their variations, and anomalies. The technique is based on the paramagnetic features of deoxyhemoglobin, which includes the four unpaired electrons of the iron atom. The deep cerebral venous system-related structures, such as the anterior septal, thalamostriate, and internal cerebral veins can particularly be elaborated by SWI MR sequencing with high definition (15). Normal sinuses and veins are mostly visualized by SWI as hypointense in color (Figure 3A), whereas thrombosed venous segments are visualized as hyperintense and relatively dilated when compared with the adjacent venous structures (7). Deoxyhemoglobin is a paramagnetic molecule that exists in high concentrations in venous vascularity and causes loss of signal (hypointensity) in MRI. In the presence of arterial or venous thrombosis, stasis due to the slowing or absence of blood flow results in an increased concentration of deoxyhemoglobinin vascular compartments, which then act as an endogen contrast medium and is seen as hypointense in SWI sequences $(15,16)$.

SWI is an effective method of demonstrating hemorrhagic venous infection and thrombosis in the sinus and cortical veins, and it can be essential in evaluating cerebral venous sinus thrombosis; venous stasis within dilated cortical and transmedullary veins and collateral slow flow can additionally be elaborated (17).SWI imaging may also be practical in screening the effectiveness of 


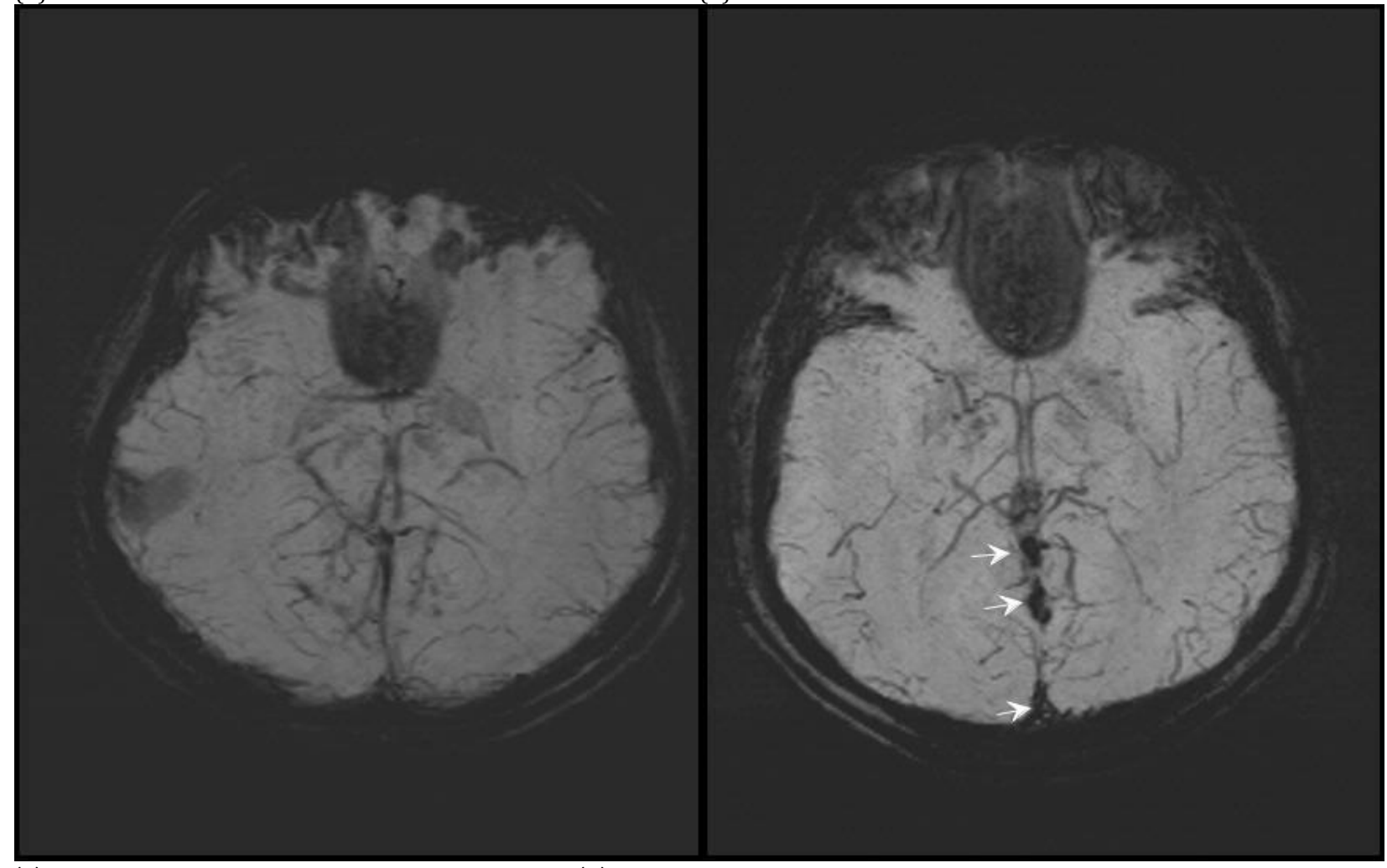

(C)

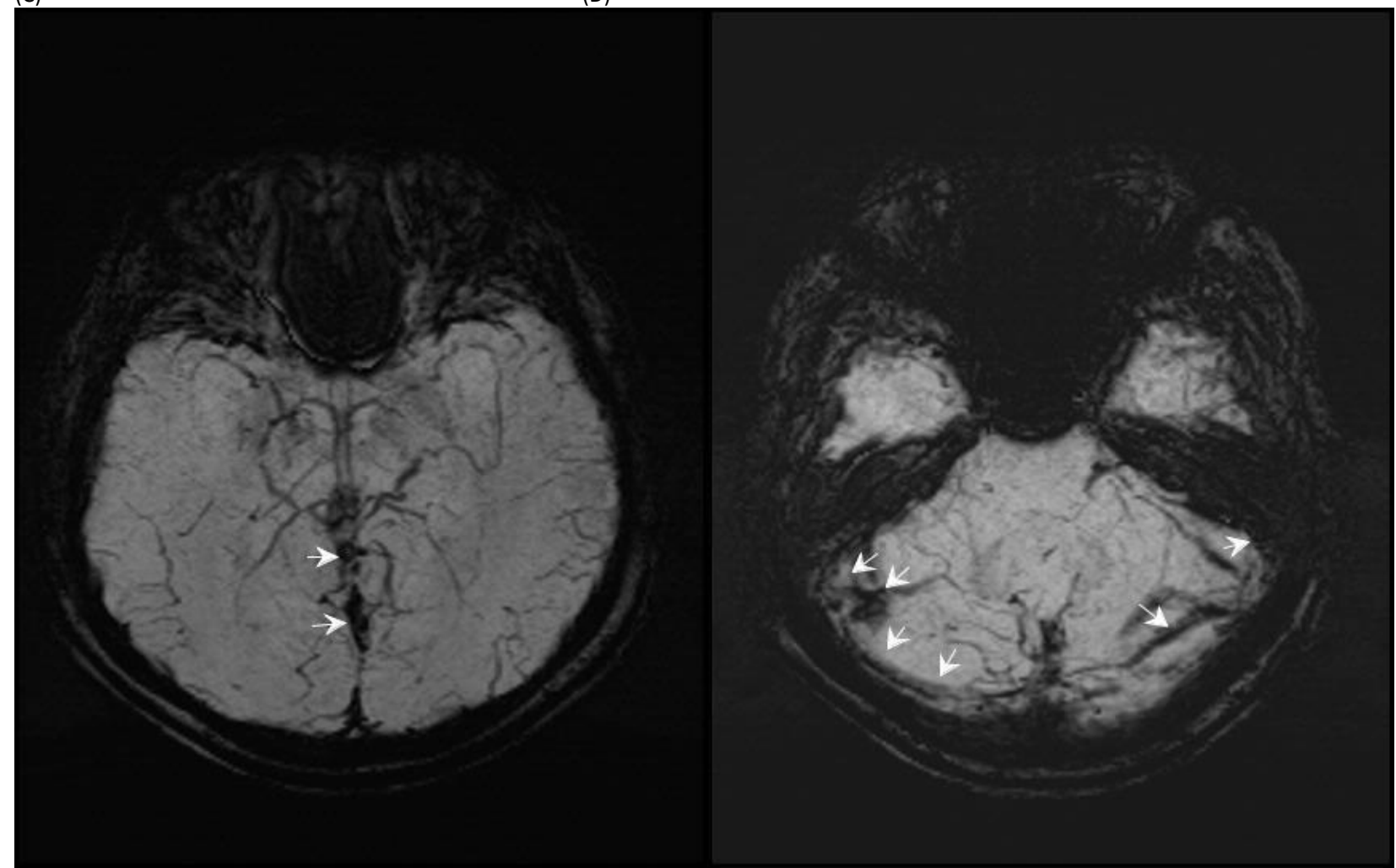

Figure 3. Normal venous structures visualized in ordinary axial SWI MIP sections (A). In axial SWI MIP sections, dilatation of venous vascularity and distinct hypointensity (arrow) due to thrombosis are revealed within the bilateral transverse sinus, straight sinus, and other posterior fossa veins (B-D). 
the adopted venous thrombolytic therapy (18). In a study by Boukobza et al., the authors reported that T2* gradient-echo sequencing was superior to other standard MRI sequences in determining early or delayed phased isolated cortical venous thrombosis (19).

It has been reported recently that SWI is more sensitive in determining CVT than T1, T2, and FLAIR-weighted imaging, and that it can showsubarachnoid and intracerebral hemorrhage (20). In our case, a thrombus was detected within the main cerebral venous vascularity, including the superior sagittal sinus, bilateral transverse, and sigmoid sinus. Thrombi in deep cerebral veins such as the straight sinus and posterior fossa veins can even be visualized by SWI sequence. Thus, it can be seen that SWI sequencing is superior to other MR sequencing methods in revealing thrombotic veins in the posterior fossa in particular.

In conclusion, SWI can promptly identifyvenous thrombosis, contribute to the diagnosis, and provide useful additional information. We are of the opinion that in suspected cases of CVT, SWI should also be performed along with routine MRI. We consider that SWI sequencing is more sensitive than other MR sequencing in determination thrombosis in posterior fossa, cortical, and deep cerebral veins such as the straight sinus.

\section{REFERENCES}

1. Stam J. Current concepts: thrombosis of the cerebral veins and sinuses. N Engl J Med. 2005;352:1791-1798.

2. Ferro JM, Canhão P, Stam J, Bousser MG, Barinagarrementeria F. Prognosis of Cerebral Vein and Dural Sinus Thrombosis. Results of the International Study on Cerebral Vein and Dural Sinus Thrombosis. Stroke. 2004;35:664-70.

3. Kamışlı Ö, Arslan D, SibelAltınayar S, Kamışlı S, Kablan Y, Özcan C. Serebral Venöz Sinüs Trombozu: Klinik Değerlendirme. Türk Beyin Damar Hastalıkları Dergisi. Journal of Turkish Cerebrovascular Diseases 2009; 15; 3942.

4. Kaklamani VG, Vaiopoulos G, Kaklamanis PG. Behçet's disease. Seminars in arthritis and rheumatism. 1988;27:197-217.

5. Akman-Demir G, Yeșilot N, Serdaroğlu P. Behçet Hastalığında Nörolojik Tutulum: Klinik Özellikler, Tanı ve Tedaviye Yaklaşım. Journal of Neurological Sciences [Turkish]. 2006;23:3-7.
6. Gasparotti R, Pinelli L, Liserre R. New MR sequences in daily practice: susceptibility weighted imaging. A pictorial essay.Insights Imaging.2011; 2:335-347.

7. Haacke EM, Xu Y, Cheng YC, et al. Susceptibility weighted imaging (SWI). MagnReson Med. 2004;52:612-618.

8. Şenol MG, Toğrol E, Kaşıkçı T, Tekeli H, Özdağ F, Saraçoğlu M. Serebral Venöz Tromboz: 16 Olgunun İncelenmesi Düzce Tıp Fakültesi Dergisi. 2009;11:32-37

9. Leach JL, Strub WM, Gaskill-Shipley MF. Cerebral venous thrombus signal intensity and susceptibility effects on gradient recalled-echo MR imaging. AJNR Am J Neuroradiol. 2007;28:940-945.

10. Renowden S. Cerebral venous sinus thrombosis. EurRadiol. 2004; 14: 215-226.

11. Yesilot N, Bahar S, Yilmazer S, Mutlu M, Kurtuncu M, Tuncay R, Coban O, Akman-Demir G. Cerebralvenousthrombosis in Behcet's disease compared to those associated with other etiologies. J Neurol 2009;256:1134-1142

12. Edelman RR, Johnson K, Buxton R, Shoukimas G, Rosen BR, Davis KR, Brady TJ. MR of hemorrhage: a new approach. AJNR Am J Neuroradiol. 1986; 7:751-756.

13. Kidwell CS, Chalela JA, Saver JL, et al. Comparison of MRI and CT for detection of acute intracerebral hemorrhage. JAMA 2004;292:1823-1830.

14. Kaya D, Dinçer A, Yildiz ME, Cizmeli MO, Erzen C. Acute ischemic infarction defined by a region of multiple hypointense vessels on gradient-echo T2* MR imaging at 3T. AJNR Am J Neuroradiol. 2009;30:1227-1232.

15. Nair JR, Van Hecke W, De Belder F, Venstermans C, van den Hauwe L, Van Goethem J, Parizel PM. High-resolution susceptibility-weighted imaging at $3 \mathrm{~T}$ with a 32-channel head coil: technique and clinical applications. AJR Am J Roentgenol. 2010 Oct;195(4):1007-14.

16. Kaya D, Yıldız E. Venöz Sinüs Trombozu Tanısında MRG'de Gradient Eko Sekansının Önemi. ACU Sağlık Bil Derg. 2011(2):57-60

17. Hingwala D, Kesavadas C, Thomas B, Kapilamoorthy TR. Clinical utility of susceptibility-weighted imaging in vascular diseases of thebrain. NeurolIndia. 2010 JulAug;58(4):602-7.

18. Kawabori M, Kuroda S, Kudo K, Terae S, Kaneda M, Nakayama N, Iwasaki Y. Susceptibility-weighted magnetic resonance imaging detects impaired cerebral hemodynamics in the superior sagittal sinüs thrombosiscase report. Neurol Med Chir (Tokyo). 2009 Jun;49(6):24851.

19. Boukobza M, Crassard I, Bousser MG, Chabriat H. MR imaging features of isolated cortical vein thrombosis: diagnosisand follow-up. AJNR Am J Neuroradiol. 2009 Feb;30(2):344-8. doi: 10.3174/ajnr.A1332. Epub 2008 Dec 18. PubMed PMID: 19095790.

20. Selim M, Fink J, Linfante I, Kumar S, Schlaug G, and. Caplan LR. Diagnosis of cerebral venous thrombosis with echoplanar T2*-weighted magnetic resonance imaging, Archives of Neurology. 2002;59:1021-1026. 